\title{
Clinical trial design in chronic obstructive pulmonary disease: current perspectives and considerations with regard to blinding of tiotropium
}

\author{
Kai-Michael Beeh ${ }^{1 *}$, Jutta Beier ${ }^{1}$ and James F Donohue ${ }^{2}$
}

\begin{abstract}
Randomised, double-blind, controlled trials are considered the gold standard for evaluating a pharmacological agent, as they minimise any potential bias. However, it is not always possible to perform double-blind trials, particularly for medications delivered via specific devices, e.g. inhalers. In such cases, open-label studies can be employed instead. Methods used to minimise any potential bias introduced by open-label study design include randomisation, crossover study design, and objective measurements of primary efficacy and safety variables. Concise reviews analysing the effect of blinding procedures of comparator drugs on outcomes in respiratory trials are limited. Here, we compare data from different chronic obstructive pulmonary disease trials with once-daily indacaterol versus a blinded or non-blinded comparator. The clinical trial programme for indacaterol, a once-daily, long-acting $\beta_{2}$-agonist, used tiotropium as a comparator either in an open-label or blinded fashion. Data from these studies showed that the effects of tiotropium were consistent for forced expiratory volume in 1 second, an objective measure, across blinded and non-blinded studies. The data were consistent with previous studies of double-blind tiotropium, suggesting that the open-label use of tiotropium did not introduce treatment bias. The effect of tiotropium on subjective measures (St George's Respiratory Questionnaire; transition dyspnoea index) varied slightly across blinded and non-blinded studies, indicating that minimal bias was introduced by using openlabel tiotropium. Importantly, the studies used randomised, open-label tiotropium patients to treatment allocation, a method shown to minimise bias to a greater degree than blinding. In conclusion, it is important when reporting a clinical trial to be transparent about who was blinded and how the blinding was performed; if the design is openlabel, additional efforts must be made to minimise risk of bias. If these recommendations are followed, and the data are considered in the full knowledge of any potential sources of bias, results with tiotropium suggest that data from open-label studies can provide valuable and credible evidence of the effects of therapy.
\end{abstract}

Keywords: Randomisation, Blinded, Blinding, Open-label, Indacaterol, Tiotropium, COPD

\section{Introduction}

Randomised, controlled trials (RCTs) are considered the gold standard for evaluating clinical interventions because of their ability to minimise bias [1]. Blinding is an important technique to reduce bias in clinical trials $[2,3]$. However, it is not always possible to conduct such trials; therefore, alternative study designs are often used.

* Correspondence: k.beeh@insaf-wi.de

${ }^{1}$ Insaf Respiratory Research Institute, Wiesbaden, Germany

Full list of author information is available at the end of the article
In this review, we discuss the design of RCTs of inhaled therapies in patients with chronic obstructive pulmonary disease (COPD), with particular regard to the use of blinding and open-label techniques. Data from studies of two once-daily bronchodilators used in COPD, indacaterol and tiotropium, will be used to evaluate the potential for bias in open-label studies.

\section{Blinding in clinical trials}

Administering treatment in a blinded manner is complicated when comparing medications delivered via

\section{Ciomed Central}


inhalers of different shapes and sizes [4]. In such cases, it may be necessary to employ more complex methods, such as double-dummy designs. Further difficulties may arise due to the specific properties of some products (e.g. a particular taste or sensation), which may make their identity apparent during administration. The presence of logos on branded products may also present problems if it is not possible to obtain matching placebos with identical branding or to obtain the active drug in an unbranded form. If these difficulties cannot be overcome, it may be necessary to use an open-label design [5]. While double-blind trials are considered as the gold standard for evaluating new products, open-label studies may have some advantages, such as simpler design, lower cost and closer reflection of everyday clinical practice $[2,6,7]$.

In the design of open-label studies, great care is needed to minimise possible sources of bias, which can arise in several ways [3]. For example, patients who know they are receiving an active drug, as opposed to knowing they are on placebo, may report more favourable outcomes because they expect a benefit. The patient's previous experience of a drug may also affect their reporting of subjective efficacy endpoints or adverse effects. Observers may also be biased by awareness of treatment allocation, which might affect reporting of treatment responses or adverse events. Knowledge of treatment assignment could also affect decisions about remaining on treatment or receiving concomitant medications or other therapy, as well as decisions about inclusion of results in an analysis.

\section{Minimising bias in open-label studies}

Strategies to minimise the likelihood of bias in openlabel studies include randomising patients after collection of baseline data [6] and use of crossover study designs [2]. In a crossover design trial, each patient is randomised to a sequence that includes each treatment; hence, each patient can act as their own control for treatment comparisons [2]. However, crossover designs can be limited by the potential for carry-over effects from the previous treatment and administration procedure [2]. The design of crossover studies therefore needs to incorporate appropriate wash-out and familiarisation periods. Other means of minimising bias in open-label studies include basing efficacy outcomes on objective variables [6]. Spirometry is considered the most objective, standardised and reproducible measure of airflow limitation [8], and is therefore unlikely to be subject to bias. Additionally, many clinical trials use a centralised spirometry organisation to further reduce the possibility of variability in the observation. Centralised spirometry may include provision of the same spirometry equipment to all study sites, consistent training of staff who make spirometry assessments and calibration of equipment daily.

\section{Designing clinical trials of inhaled medications in COPD}

Tiotropium is a commonly used once-daily inhaled bronchodilator for the maintenance treatment of patients with COPD and is a key comparator in evaluation of new bronchodilators. However, the use of tiotropium as a comparator presents several difficulties. Firstly, tiotropium is a hygroscopic powder and cannot be removed from the commercial capsules for repackaging into unmarked capsules. Secondly, the commercially available capsules are marked with a logo that can be seen through a window in the inhaler, making it impossible to completely mask the nature of the treatment, and for legal reasons the logo/text cannot be copied onto placebo capsules. The manufacture of tiotropium is also difficult, particularly as the drug is very unstable in the ambient air.

To overcome the problems associated with blinding, a clinical trial of a treatment administered via a dry powder inhaler (DPI) requires considerable resources and possibly assistance from the manufacturer of the comparator DPI to create blinded commercial and placebo products. Ultimately, an alternative clinical trial design may need to be used.

\section{Experience from the indacaterol clinical trial programme}

Three Phase III clinical studies have compared indacaterol with tiotropium. As blinded tiotropium was not available, alternative blinding methods were used (Table 1). The INHANCE study was performed in two stages in an adaptive seamless design [9]. In stage 1, patients were randomised to receive double-blind indacaterol 75, 150, 300, or $600 \mu \mathrm{g}$ once daily, double-blind formoterol $12 \mu \mathrm{g}$ twice daily, double-blind placebo, or open-label tiotropium $18 \mu \mathrm{g}$ once daily for 2 weeks. In stage 2, patients continued treatment with two selected doses of indacaterol (150 or $300 \mu \mathrm{g}$, based on 2-week efficacy and safety data), tiotropium, or placebo for 26 weeks, with additional patients recruited and randomised. The INTIME study was a randomised, doubleblind, crossover study in which patients received three of the following four treatments, each once-daily for 14 days and each followed by a 14-day washout: doubleblind indacaterol 150 or $300 \mu \mathrm{g}$, double-blind placebo or third-party blind tiotropium [10]. The blinding of tiotropium treatment was maintained by using a third-party blinding procedure where the study drug was prepared and provided to the patient by persons who were independent of the other clinical trial processes (described in more detail in Table 1). In the 12-week INTENSITY study, a blinded, double-dummy design was used [11]. Following a 2-week run-in, patients were randomised to 
Table 1 Description of indacaterol studies using a tiotropium comparator arm*

\begin{tabular}{|c|c|c|c|c|c|c|}
\hline Study & Description & Design & Blinding technique and reason & Patient entry criteria & Study duration & Objectives \\
\hline \multicolumn{7}{|l|}{ INHANCE [9] } \\
\hline & $\begin{array}{l}\text { Randomised, double-blind, } \\
\text { placebo-controlled study } \\
\text { assessing efficacy, safety } \\
\text { and tolerability of two } \\
\text { doses of indacaterol in } \\
\text { patients with COPD } \\
\text { using open-label tiotropium } \\
\text { as active control }\end{array}$ & $\begin{array}{l}\text { Double-blind indacaterol } \\
\text { and placebo via } \\
\text { Breezhaler } \\
\text { Open-label tiotropium } \\
\text { via HandiHaler }\end{array}$ & $\begin{array}{l}\text { No placebo to } \\
\text { tiotropium was available.* } \\
\text { Tiotropium was } \\
\text { administered open-label }\end{array}$ & $\begin{array}{l}\mathrm{FEV}_{1}<80 \text { and } \geq 30 \% \\
\text { predicted } \mathrm{FEV}_{1} / \mathrm{FVC}<70 \% \text {. } \\
\text { Smoking history } \geq 20 \\
\text { pack-years }\end{array}$ & 26 weeks & $\begin{array}{l}\text { First objective: } \\
\text { superiority of } \\
\text { indacaterol to } \\
\text { placebo using } \\
\text { trough } \mathrm{FEV}_{1} \text { at } \\
12 \text { weeks. Second } \\
\text { objective: } \\
\text { non-inferiority } \\
\text { of indacaterol to } \\
\text { tiotropium } \\
\text { using trough } \\
\mathrm{FEV}_{1} \text { at } 12 \text { weeks }\end{array}$ \\
\hline INTIME [10] & $\begin{array}{l}\text { Randomised, blinded, } \\
\text { placebo-controlled, } \\
\text { multicentre, three-period, } \\
\text { incomplete block, } \\
\text { multi-dose crossover } \\
\text { study to determine } \\
\text { the effect on lung function } \\
\text { of indacaterol in patients } \\
\text { with moderate-to-severe } \\
\text { COPD, using tiotropium } \\
\text { as an active control }\end{array}$ & $\begin{array}{l}\text { Double-blind indacaterol } \\
\text { and placebo via Breezhaler } \\
\text { Third-party blinding of } \\
\text { tiotropium (via HandiHaler }\end{array}$ & $\begin{array}{l}\text { Indacaterol and its matching placebo } \\
\text { were made identical in appearance } \\
\text { and were dispensed in such a manner } \\
\text { to make them indistinguishable } \\
\text { to patients and all blinded study personnel. } \\
\text { An exact physical match to tiotropium } \\
\text { was not available. Blinding of } \\
\text { tiotropium was maintained by use } \\
\text { of third-party blinding procedures }\end{array}$ & $\begin{array}{l}\mathrm{FEV}_{1}<80 \text { and } \geq 30 \% \\
\text { predicted } \mathrm{FEV}_{1} / \mathrm{FVC}<70 \% \text {. } \\
\text { Smoking history } \geq 10 \\
\text { pack-years }\end{array}$ & $\begin{array}{l}70 \text { days ( } 14 \text { days } \\
\text { treatment with four } \\
\text { different treatments } \\
\text { in three separate } \\
\text { periods with a } \\
\text { washout of } 14 \\
\text { days between } \\
\text { treatments) }\end{array}$ & $\begin{array}{l}\text { First objective: } \\
\text { superiority of } \\
\text { indacaterol to } \\
\text { placebo using } \\
\text { trough } \mathrm{FEV}_{1} \text { at } \\
14 \text { days. Second } \\
\text { objective: } \\
\text { non-inferiority of } \\
\text { indacaterol to } \\
\text { tiotropium using } \\
\text { trough } \mathrm{FEV}_{1} \text { at } \\
14 \text { days }\end{array}$ \\
\hline INTENSITY [11] & $\begin{array}{l}\text { Randomised, parallel-group, } \\
\text { blinded, double-dummy } \\
\text { study to compare the } \\
\text { efficacy and safety of } \\
\text { indacaterol delivered via a } \\
\text { SDDPI with tiotropium } \\
\text { delivered via a HandiHaler } \\
\text { in patients with } \\
\text { moderate-to-severe COPD }\end{array}$ & $\begin{array}{l}\text { Blind, double-dummy } \\
\text { indacaterol via Breezhaler } \\
\text { versus tiotropium } \\
\text { via HandiHaler }\end{array}$ & $\begin{array}{l}\text { Patients receiving indacaterol also took } \\
\text { placebo via the inhaler used for tiotropium, } \\
\text { and patients receiving tiotropium took } \\
\text { placebo via the inhaler used for indacaterol. } \\
\text { The colour of the capsules was compatible, but } \\
\text { the placebo did not have the markings. The } \\
\text { blinding of tiotropium was maintained } \\
\text { by use of an unblinded individual, who was } \\
\text { not involved in any study assessments, to } \\
\text { administer treatment. Patients and } \\
\text { investigators therefore remained blind to } \\
\text { treatment allocation }\end{array}$ & $\begin{array}{l}\mathrm{FEV}_{1}<80 \text { and } \geq 30 \% \\
\text { predicted } \mathrm{FEV}_{1} / \mathrm{FVC}<70 \% \text {. } \\
\text { Smoking history } \geq 10 \\
\text { pack-years }\end{array}$ & 12 weeks & $\begin{array}{l}\text { First objective: } \\
\text { non-inferiority of } \\
\text { indacaterol to } \\
\text { tiotropium using } \\
{\text { trough } \mathrm{FEV}_{1} \text { at }}_{12 \text { weeks Second }} \\
\text { objective: superiority } \\
\text { of indacaterol to } \\
\text { tiotropium using } \\
\text { trough } \mathrm{FEV}_{1} \text { at } \\
12 \text { weeks }\end{array}$ \\
\hline
\end{tabular}

*The blinding of tiotropium is complicated by the fact that patients place a capsule in the inhalation device (HandiHaler ${ }^{\circledR}$ ) and are able to see the logo on the capsule through a window in the device. Neither placebo tiotropium capsules with such a logo nor active tiotropium capsules without such a logo could be obtained for use in these studies of indacaterol; therefore, it was not possible to conduct traditionally designed double-blind studies.

${ }^{\dagger}$ Study drug was prepared and provided to the patient each morning, either at home or in the clinic by persons who were independent of the other clinical trial processes (referred to as 'independent study blinding co-ordinators', ISBCs) to preserve the integrity of the blind. Two ISBCs were required for each daily study drug administration to each patient. The first (non-blinded) ISBC (who had no contact with the patient)

prepared the study drugs and devices. The second (blinded) ISBC provided the patient with the prepared study drug and devices, monitored administration of the drug by patients and ensured that the blinding was maintained throughout. Both ISBCs completed the third-party blinding log for every drug administration, to provide evidence that the blinding procedure was strictly followed.

COPD: chronic obstructive pulmonary disease; FEV $_{1}$ : forced expiratory volume in 1 second; FVC: forced vital capacity; SDDPI: single dose dry powder inhaler. 
Table 2 Key results from indacaterol studies with a tiotropium comparator arm and double-blind studies with tiotropium as the primary treatment of interest

\begin{tabular}{|c|c|c|c|c|c|c|}
\hline \multirow[t]{2}{*}{ Study } & \multirow[t]{2}{*}{ Design } & \multirow[t]{2}{*}{ Patient characteristics } & \multirow[t]{2}{*}{ Time } & \multirow[t]{2}{*}{$\begin{array}{l}\text { Trough } \mathrm{FEV}_{1} \text { versus } \\
\text { placebo }(\mathrm{mL})\end{array}$} & \multicolumn{2}{|c|}{$\begin{array}{c}\text { Proportion of patients } \\
\text { achieving MCID }\end{array}$} \\
\hline & & & & & SGRQ (\%) & TDI (\%) \\
\hline \multicolumn{7}{|c|}{ Indacaterol versus tiotropium studies } \\
\hline \multirow[t]{6}{*}{ INHANCE [9] } & \multirow[t]{6}{*}{$\mathrm{OL}^{*}$} & \multirow{6}{*}{$\begin{array}{l}\mathrm{FEV}_{1}<80 \% \text { and } \geq 30 \% \text { predicted; } \\
\mathrm{FEV}_{1} / \mathrm{FVC}<0.7 ; \text { Mean } \mathrm{FEV}_{1} \% \text { predicted }{ }^{\oplus} \text { : } \\
\text { Indacaterol } 150 \mu \mathrm{g} 56.1 \text {, Indacaterol } \\
300 \mu \mathrm{g} 56.3 \text {, Tiotropium 53.9, } \\
\text { Placebo } 56.1\end{array}$} & \multirow[t]{3}{*}{$12 w k$} & Tiotropium: 140 & $44.9^{\dagger}$ & $55.0^{\dagger}$ \\
\hline & & & & 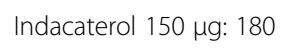 & $51.9^{\dagger}$ & $58.9^{\dagger}$ \\
\hline & & & & Indacaterol 300 g: 180 & $50.1^{\dagger}$ & $65.8^{\dagger}$ \\
\hline & & & \multirow[t]{3}{*}{$26 w k$} & Tiotropium: 140 & 47.3 & 57.3 \\
\hline & & & & 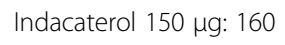 & 57.8 & 62.4 \\
\hline & & & & Indacaterol 300 Mg: 180 & 52.5 & 70.8 \\
\hline \multirow[t]{3}{*}{ INTIME [10] } & \multirow[t]{3}{*}{$\mathrm{TPB}$} & \multirow{3}{*}{$\begin{array}{l}\mathrm{FEV}_{1}<80 \text { and } \geq 30 \% \text { predicted; } \\
\mathrm{FEV}_{1} / \mathrm{FVC}<0.7 ; \text { Mean FEV } 1 \% \text { predicted } 56.7\end{array}$} & \multirow[t]{3}{*}{$2 w k$} & Tiotropium: 120 & - & - \\
\hline & & & & Indacaterol $150 \mu \mathrm{g}: 170$ & - & - \\
\hline & & & & 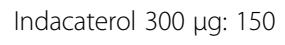 & - & - \\
\hline \multirow[t]{2}{*}{ INTENSITY [11] } & \multirow[t]{2}{*}{ B } & \multirow{2}{*}{$\begin{array}{l}\mathrm{FEV}_{1}<80 \text { and } \geq 30 \% \text { predicted; } \\
\mathrm{FEV}_{1} / \mathrm{FVC}<0.7 ; \text { Mean } \mathrm{FEV}_{1} \% \text { predicted }{ }^{\boldsymbol{}} \text { : } \\
\text { Indacaterol 54.6, Tiotropium } 54.3\end{array}$} & \multirow[t]{2}{*}{$12 \mathrm{wk}$} & Tiotropium: - & 42.5 & 50.1 \\
\hline & & & & Indacaterol $150 \mu \mathrm{g}$ & 50.5 & 57.9 \\
\hline \multicolumn{7}{|c|}{ Tiotropium versus placebo studies } \\
\hline Beeh et al. 2006 [15] & $\mathrm{DB}$ & $\begin{array}{l}\mathrm{FEV}_{1} \leq 70 \% \text { predicted; } \mathrm{FEV}_{1} / \mathrm{FVC}<0.7^{\ddagger} \\
\text { Mean FEV } \\
\text { Tiotropium } 45.3 \text {, Placedicted }{ }^{*} \text { Total } 45.4 \\
\text { Th.7 }\end{array}$ & $12 w k$ & 79 & - & - \\
\hline Freeman et al. 2007 [16] & DB & $\begin{array}{l}\mathrm{FEV}_{1} 30-65 \% \text { predicted; } \mathrm{FEV}_{1} / \mathrm{FVC}<0.7^{\S} \\
\text { Mean }^{\S E V_{1} \% \text { predicted }} \text { : Total } 48.9 \\
\text { Tiotropium 47.9, Placebo } 49.9\end{array}$ & $12 w k$ & 60 & - & - \\
\hline Johansson et al. 2008 [17] & DB & $\begin{array}{l}\mathrm{FEV}_{1}>60 \% \text { predicted; } \mathrm{FEV}_{1} / \mathrm{FVC}<0.7^{\sigma} \\
\text { Mean FEV } 1 \text { \% predicted } \\
\text { Tiotropium } 73.6 \text {, Placebo } 73.2\end{array}$ & $12 w k$ & 118 & - & - \\
\hline Moita et al. 2008 [18] & $\mathrm{DB}$ & 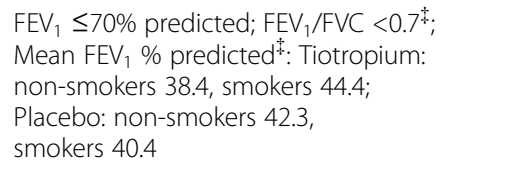 & $12 w k$ & 102 & - & - \\
\hline Verkindre et al. 2006 [19] & $\mathrm{DB}$ & $\begin{array}{l}\mathrm{FEV}_{1} \leq 50 \% \text { predicted; } \mathrm{FEV}_{1} / \mathrm{SVC} \\
\leq 0.7 ; \text { lung hyperinflation }{ }^{*} \text {; Mean FEV } \% \\
\text { predicted:: Tiotropium } 34.7 \text {, } \\
\text { Placebo } 35.8\end{array}$ & $12 w k$ & 110 & 59 & - \\
\hline \multirow[t]{2}{*}{ Niewoehner et al. 2005 [20] } & \multirow[t]{2}{*}{$\mathrm{DB}$} & $\begin{array}{l}\mathrm{FEV}_{1} \leq 60 \% \text { predicted; } \mathrm{FEV}_{1} / \mathrm{FVC}<0.7^{*} \\
\text { Mean } \mathrm{FEV}_{1} \% \text { predicted }{ }^{*} \text { : Tiotropium } 35.6 \\
\text { Placebo } 35.6\end{array}$ & $13 w k$ & 100 & - & - \\
\hline & & & $26 w k$ & 100 & - & - \\
\hline Brusasco et al. 2003 [21] & $\mathrm{DB}$ & $\begin{array}{l}\mathrm{FEV}_{1} \leq 65 \% \text { predicted; } \mathrm{FEV}_{1} / \mathrm{FVC}<0.7^{\ddagger} \\
\text { Mean } \mathrm{FEV}_{1} \% \text { predicted }{ }^{*} \text { : Tiotropium } 39.2 \\
\text { Placebo } 38.7\end{array}$ & $26 w k$ & 120 & 48.9 & 43.1 \\
\hline \multirow[t]{3}{*}{ Tonnel et al. 2008 [22] } & \multirow[t]{3}{*}{ DB } & $\begin{array}{l}\mathrm{FEV}_{1} 20-70 \% \text { predicted; } \mathrm{FEV}_{1} / \mathrm{FVC} 0.7^{\#} ; \\
\text { Mean } \mathrm{FEV}_{1} \% \text { predicted }{ }^{+} \text {: Tiotropium } 47.5 \\
\text { Placebo } 46.2\end{array}$ & $12 w k$ & - & $60^{\|}$ & - \\
\hline & & & $26 w k$ & - & $60^{\| 1}$ & - \\
\hline & & & $39 w k$ & 100 & 59.1 & - \\
\hline Chan et al. 2007 [23] & $\mathrm{DB}$ & $\begin{array}{l}\mathrm{FEV}_{1} \leq 65 \% \text { predicted; } \mathrm{FEV}_{1} / \mathrm{FVC}<0.7^{\ddagger} \\
\text { Mean FEV } \% \text { predicted": Tiotropium } 39.4 \\
\text { Placebo } 39.3\end{array}$ & $11 w k$ & $100^{\|}$ & - & - \\
\hline
\end{tabular}


Table 2 Key results from indacaterol studies with a tiotropium comparator arm and double-blind studies with tiotropium as the primary treatment of interest (Continued)

\begin{tabular}{|c|c|c|c|c|c|c|}
\hline & & & $48 w k$ & 100 & 53 & - \\
\hline \multirow[t]{3}{*}{ Casaburi et al. 2002 [24] } & DB & $\begin{array}{l}\mathrm{FEV}_{1} \leq 65 \% \text { predicted; } \mathrm{FEV}_{1} / \mathrm{FVC}<0.7^{*} \\
\text { Mean } \mathrm{FEV}_{1} \% \text { predicted } \% \text { Tiotropium } 39.1 \\
\text { Placebo } 38.1\end{array}$ & $13 w k$ & $148^{\|}$ & - & $42-47^{\approx}$ \\
\hline & & & $25 w k$ & $148^{\|}$ & - & $42-47 \approx$ \\
\hline & & & $1 \mathrm{yr}$ & $150^{\|}$ & 49 & $47^{\approx}$ \\
\hline \multirow[t]{2}{*}{ Tashkin et al. 2008 [25] } & DB & $\begin{array}{l}\mathrm{FEV}_{1} \leq 70 \% \text { predicted; } \mathrm{FEV}_{1} / \mathrm{FVC}<0.7^{\uparrow} \\
\text { Mean } \mathrm{FEV}_{1} \% \text { predicted } \\
\text { Placebo } 47.4\end{array}$ & $26 w k$ & $100^{\|}$ & - & - \\
\hline & & & $4 \mathrm{yr}$ & 87-103 & $45 \%$ & - \\
\hline
\end{tabular}

Data are least square mean for INHANCE, INTIME and INTENSITY; other publications did not describe the type of mean.

*Tiotropium arm (indacaterol and placebo were DB)

${ }^{\dagger}$ Data on file at Novartis.

Not stated whether pre- or post-bronchodilator.

\$Pre-bronchodilator.

Post-bronchodilator.

\#Pre- and post-bronchodilator.

"Estimated from a figure.

$\approx$ Values are given as $42-47 \%$ across all timepoints up to 2 years (greatest improvement versus baseline was seen at 2 years).

Definitions of trough FEV 1 varied (mean of 23 hours 10 minutes and 23 hours 45 minutes post-dose for INHANCE, INTIME and INTENSITY, Beeh et al. 2006 [15],

Verkindre et al. 2006 [19] and Brusasco et al. 2003 [21]; 10 minutes pre-dose for Freeman et al. 2007 [16], Johansson et al. 2008 [17] and Chan et al. 2007 [23]; 30

minutes pre-dose for Tonnel et al. 2008 [22]; 1 hour pre-dose for Casaburi et al. 2002 [24]; and 'pre-dose' for Niewoehner et al. 2005 [20] and Tashkin et al. 2008

[25]. All studies recruited patients aged $\geq 40$ years with a smoking history of $\geq 10$ pack-years ( $\geq 20$ years for INHANCE).

MCID: minimum clinically important difference; SGRQ: St. George's Respiratory Questionnaire; TDI: transition dyspnoea index; OL: open-label; FEV ${ }_{1}$ : forced

expiratory volume in 1 second; FVC: forced vital capacity; TPB: third-party blinding; B: blinded; DB: double-blind; SVC: slow vital capacity.

treatment with indacaterol $150 \mu \mathrm{g}$ or tiotropium $18 \mu \mathrm{g}$, each once-daily for 12 weeks. Patients receiving indacaterol also took a placebo via the inhaler used for tiotropium, and patients receiving tiotropium took a placebo via the inhaler used for indacaterol. Blinding was achieved by specifying that study medications were dispensed by a third party not involved in other aspects of the study. In all three studies, indacaterol was administered via the Breezhaler ${ }^{\circledR}$ DPI device and tiotropium via the Handihaler ${ }^{\circledR}$ DPI device.

Patient populations were similar across the three studies, which enrolled patients with moderate-to-severe COPD (forced expiratory volume in 1 second $\left[\mathrm{FEV}_{1}\right]$ $<80 \%$ and $\geq 30 \%$ predicted; $\mathrm{FEV}_{1}$ /forced vital capacity $[F V C]<0.7)[12-14]$, and a smoking history of $\geq 10$ packyears (INTIME and INTENSITY $[10,11]$ ) or $\geq 20$ packyears (INHANCE [9]). The primary endpoint was trough $\mathrm{FEV}_{1}$ (an objective endpoint) in all three studies, with the primary comparisons being indacaterol versus placebo at Week 12 in INHANCE [9], Week 2 in INTIME [10] and indacaterol versus tiotropium at Week 12 in INTENSITY [11].

\section{Effect of study blinding on objective measures: lung function}

The results of 24-hours post-dose (trough) $\mathrm{FEV}_{1}$ for active treatment versus placebo in the INHANCE and INTIME studies are shown in Table 2. The treatment differences for tiotropium versus placebo were similar across both studies, even though they differed in blinding of the tiotropium arm $[9,10]$. Treatment differences for indacaterol versus placebo were also consistent across both studies.

Table 2 also shows $\mathrm{FEV}_{1}$ data from previous studies in which tiotropium was the primary treatment of interest. It should be noted that there were differences in entry criteria and in definitions of trough $\mathrm{FEV}_{1}$ between studies.

In the INHANCE study, the difference in trough $\mathrm{FEV}_{1}$ between open-label tiotropium and placebo was $140 \mathrm{~mL}$ at both Weeks 12 and 26 [9]. These values are similar to those recorded during the previous double-blind studies of tiotropium at 12 weeks $(60-148 \mathrm{~mL}), 26$ weeks (100$148 \mathrm{~mL})$ and over the longer term (100-150 mL; Table 2 and Figure 1).

These findings suggest that there was no bias against tiotropium for $\mathrm{FEV}_{1}$ in the open-label INHANCE study. The $140 \mathrm{~mL}$ difference between tiotropium and placebo in the indacaterol studies was greater than the differences seen at 12 and 26 weeks in the majority of the double-blind studies of tiotropium, raising the possibility that the bias, if any, was favouring the performance of tiotropium (Figure 1). However, the variation in $\mathrm{FEV}_{1}$ even between the previous double-blind studies may partly reflect differences in enrolment criteria, such as COPD severity or patient characteristics.

In the INTENSITY study, which did not include a placebo arm, trough $\mathrm{FEV}_{1}$ at Week 12 was similar with indacaterol $(144 \mathrm{~mL})$ and tiotropium $(143 \mathrm{~mL})$, and non-inferiority was demonstrated [11]. Mean changes 
from baseline in trough $\mathrm{FEV}_{1}$ were also similar between indacaterol $(130 \mathrm{~mL})$ and tiotropium $(120 \mathrm{~mL})$ in that study.

\section{Effect of study blinding on subjective measures: health- related quality of life}

As well as $\mathrm{FEV}_{1}$, many regulatory authorities recommend that clinical trials in COPD include an endpoint that reflects clinical benefit of treatment using a validated measure, such as the St. George's Respiratory Questionnaire (SGRQ) [26,27].

The SGRQ is used to assess health status in patients with chronic respiratory disease and was included as a measure in the INHANCE and INTENSITY studies. The questionnaire, which is completed by the patient, comprises of 50 questions in three domains: symptoms, activity (limitations) and impacts (of disease), which are calculated to provide a score between 0 (best) and 100 (worst). The minimal clinically important difference (MCID) for SGRQ score that is generally accepted as indicating an improvement over placebo or from baseline is -4 units [28].

After 12 weeks of treatment, the MCID for change in SGRQ from baseline was achieved by $44.9 \%$ of tiotropium-treated patients (with a mean improvement of -1.1 units) in the INHANCE study (open-label tiotropium) and $42.5 \%$ of patients (with a mean improvement of -3.0 units) in the INTENSITY study (blinded tiotropium) [11,29] (Table 2). These values are slightly lower than those recorded at 12 weeks in studies where tiotropium was the primary treatment of interest (Figure 2).
At 26 weeks, $47.3 \%$ of tiotropium-treated patients in INHANCE achieved the MCID for change in SGRQ (with a mean improvement of -1.0 units) compared with a range of $49-60 \%$ in published tiotropium studies. Overall, the percentage of patients treated with openlabel tiotropium in INHANCE who achieved the MCID for change in SGRQ at 12 and 26 weeks, were within the range of values recorded across all of the double-blind tiotropium studies over the durations of 12 weeks to 4 years (Table 2 and Figure 2). Again, it should be noted that, even in double-blind studies of tiotropium, there was variability in the proportion of patients who achieved the MCID for SGRQ (and in the mean improvement scores; -2.7 to -6.5 ).

These findings indicate that minimal bias was introduced with the open-label design of the tiotropium comparator arm in the INHANCE study.

\section{Dyspnoea - transition dyspnoea index (TDI)}

Dyspnoea, or breathlessness, is the major limiting symptom for COPD patients and is often measured using the TDI [30], a tool recommended by regulatory authorities for inclusion in clinical trials of treatments for COPD [26].

The TDI is a multidimensional instrument that measures change from the baseline dyspnoea index (BDI) over time [31]. The BDI considers three components (functional impairment, magnitude of task and magnitude of effort), each rated from 0 (severe dyspnoea) to 4 (no dyspnoea). The TDI measures changes from baseline in each domain of the BDI on a scale of +3 (major improvement) to -3 (major deterioration) and has been

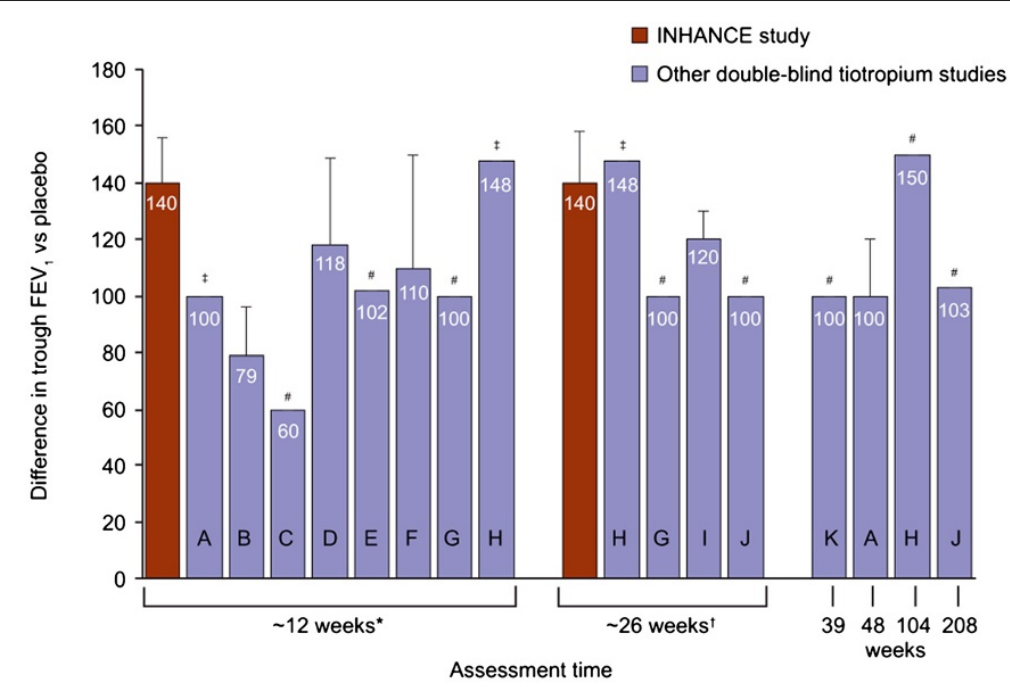

Figure 1 Differences in trough forced expiratory volume in 1 second $\left(\mathrm{FEV}_{1}\right)$ between tiotropium and placebo in INHANCE [9] and studies in which tiotropium was the primary treatment of investigation. Values are means and standard errors. *Includes assessments made at 11,12 and 13 weeks; ${ }^{\dagger}$ Includes assessments made at 25 weeks; ${ }^{*}$ Estimated from a figure (no standard error available); ${ }^{*}$ No standard error available. 


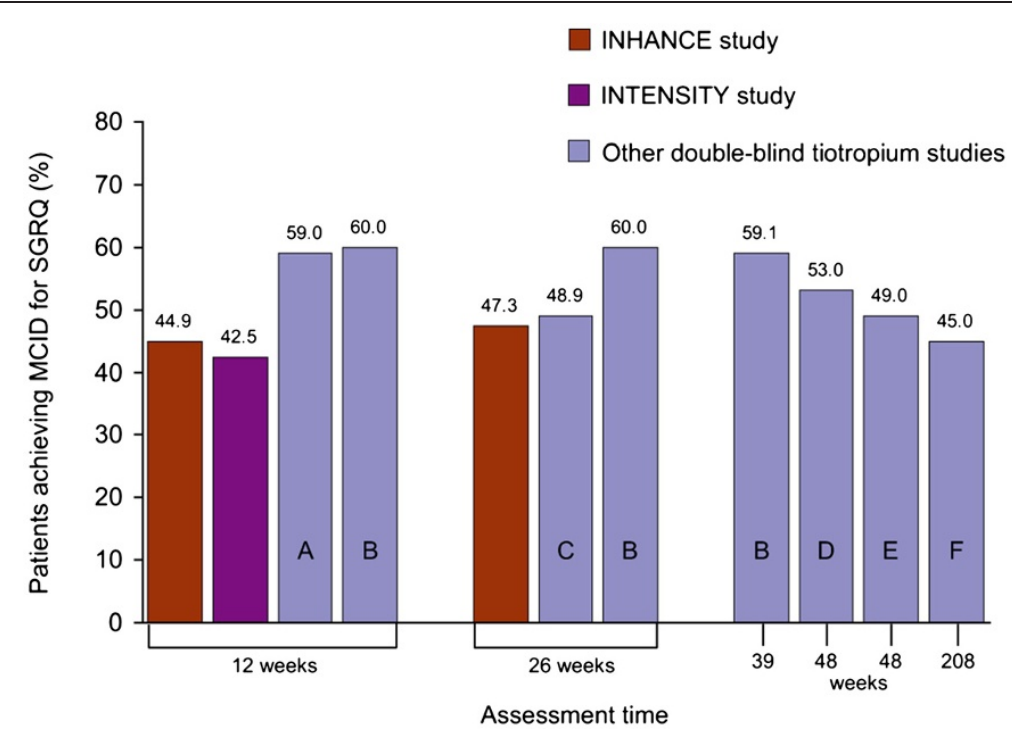

Figure 2 Percentages of tiotropium-treated patients achieving the minimum clinically important difference (MCID) for St. George's Respiratory Questionnaire (SGRQ) score in INHANCE [29], INTENSITY [11] and other studies in which tiotropium was the primary treatment of investigation.

shown to be valid, reliable and responsive [31,32]. The MCID for the TDI is an improvement from the BDI score of $\geq 1$ unit [33].

The proportion of patients achieving an improvement in TDI equal or greater to the MCID was assessed in the INHANCE and INTENSITY trials of indacaterol (Table 2). In the INHANCE study (open-label tiotropium), the MCID for TDI was achieved by $55.0 \%$ of tiotropium-treated patients at 12 weeks (with a mean improvement of 0.75 points) and $57.3 \%$ at 26 weeks (with a mean improvement of 0.87 points) [9], while in the INTENSITY study (blinded tiotropium), 50.1\% of tiotropium-treated patients achieved the MCID at 12 weeks (with a mean improvement of 1.43 points) [11]. These values are slightly higher than the values recorded during the previous studies of tiotropium [21,24], again demonstrating that the open-label design of INHANCE did not result in a bias against tiotropium (mean improvement of $0.8-1.28$ points) (Table 2 and Figure 3 ).

\section{Adverse events}

In the INHANCE study, the overall incidence of adverse events and the most commonly occurring adverse events were similar across the treatment groups (indacaterol 150 or $300 \mu \mathrm{g}$, tiotropium, or placebo) [9]. Respiratory tract infections and respiratory events were the most common type of adverse events, serious events, and those leading to withdrawal of study treatment. In the INTIME study, the overall incidence of adverse events was similar across all treatments (indacaterol 150 or 300 $\mu \mathrm{g}$, tiotropium or placebo), and these were predominantly mild or moderate in severity [10]. The most frequent adverse events were cough, COPD exacerbation, and nasopharyngitis. In the INTENSITY study, adverse events were reported for similar proportions of patients in the two treatment groups (indacaterol and tiotropium), with the most common events generally reflecting the typical disease characteristics of COPD [11]. These results reflect adverse events observed in previous double-blind trials of tiotropium compared with placebo $[17,18,22,24,25]$.

\section{Additional evidence on the effect of study blinding on treatment effect}

It is worth noting that the third-party blinding procedure used in the INTIME study required administration of the study drug to the patient by a blinded individual, and therefore the forced high compliance may potentially bias results over what might be seen in a more traditional clinical trial. In addition, the high manpower intensity required for third-party blinding may limit these studies to short periods of time.

Previous reports on the effects of blinding in RCTs have been conflicting. Several studies examining the effects of differing blinding techniques in RCTs from a range of therapy areas have found that open-label studies tend to exaggerate the benefits of treatment when they are included in meta-analyses [34-37]. For example, Schulz et al. found that in open-label RCTs, odds ratios were exaggerated by $17 \%$ [34]. Other studies of RCT blinding have found that an open-label trial design is not associated with treatment bias [38-40]. Moreover, investigations have shown that the adequacy of randomisation 


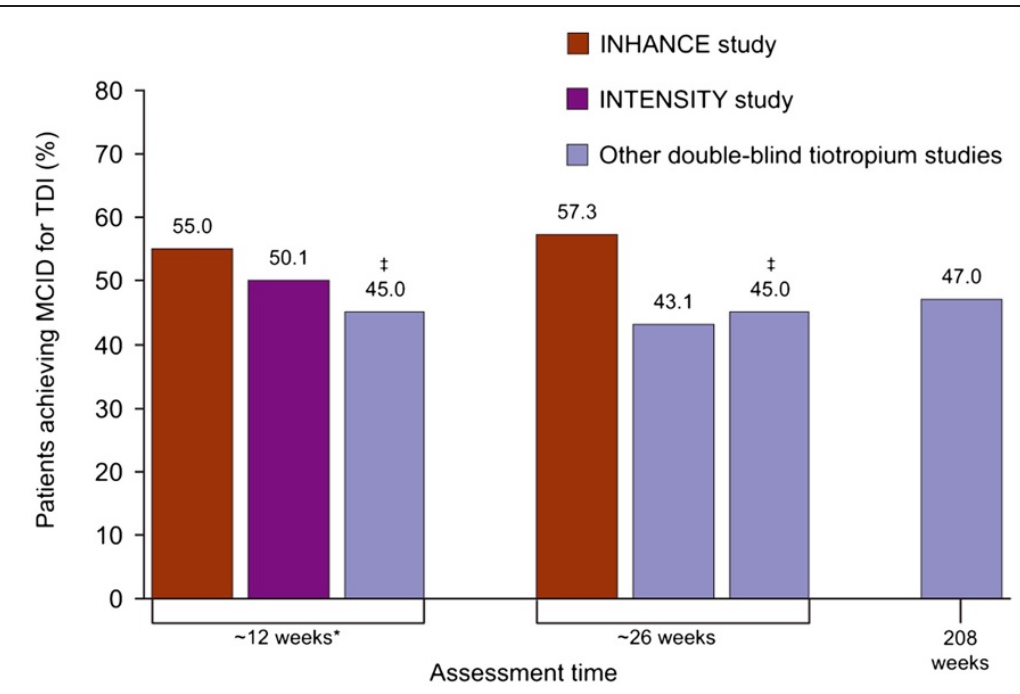

Figure 3 Percentages of tiotropium-treated patients achieving the minimum clinically important difference (MCID) for transition dyspnoea index (TDI) in INHANCE [9], INTENSITY [11] and other studies in which tiotropium was the primary treatment of investigation. *Includes assessments made at 13 weeks; ${ }^{\dagger}$ Includes assessments made at 25 weeks; ${ }^{*}$ Precise value is not given (values stated as range of $42-47 \%$ across all timepoints).

has a greater influence on treatment bias than blinding [39].

Observational studies are considered inherently biased as they are both open-label and non-randomised [41,42]. However, a comparison of treatment bias in observational studies versus RCTs found that in 17 out of 19 analyses, the estimates of treatment effects from observational studies were similar to those from RCTs; in only two of the 19 analyses did the combined magnitude of the treatment effect in the observational studies lie outside the $95 \%$ confidence interval for the combined magnitude in the RCTs [43]. Data from epidemiological studies, while very different in design and quality from a RCT indicate that objective outcomes are less affected by bias associated with an open-label study design than subjective outcomes [44]. Thus, even under conditions where bias is expected, an open-label study design need not introduce bias, particularly if assessments are based on objective measurements.

\section{Conclusions}

Double-blind RCTs remain the gold standard for evaluating interventions in chronic diseases such as COPD. However, many drugs in COPD, particularly bronchodilators, have an acute effect on both subjective and objective outcomes, therefore full blinding cannot be guaranteed. If an open-label design is chosen, the potential for bias must be taken into account and the selection of outcome measures is of pivotal importance. Measures such as airway function are considered objective and less prone to bias, and are therefore recommended as primary endpoints. Despite possible limitations associated with functional endpoints such as $\mathrm{FEV}_{1}$ in COPD, these variables have proven reliable, are subject to little or no placebo effect, and have produced consistent results that are largely independent of study population, treatment duration and differences in study design and blinding.

This low likelihood of bias with objective measures of airway function is also supported by the fact that spirometry has rigorous standards for performance in clinical trials; any incomplete effort that can introduce bias is detected by the technician/central agency and not included. Thus, selection of an objective outcome measure such as $\mathrm{FEV}_{1}$ in an open-label study in COPD is unlikely to introduce relevant bias if technical requirements are met and established guidelines are followed [45].

While this holds true for $\mathrm{FEV}_{1}$ and, potentially, other objective endpoints in COPD, the inclusion of more subjective, patient-reported outcomes may pose a larger challenge. However, data from studies comparing indacaterol with tiotropium demonstrate that the effects of tiotropium on subjective measures (SGRQ; TDI) vary slightly across blinded and non-blinded studies, indicating that minimal bias was introduced by using openlabel tiotropium. It is likely that the appropriate use of randomisation in the comparative studies was an important factor in minimising potential bias. Nevertheless, the extent to which instruments such as symptom indices or health status questionnaires are affected by blinding issues in the absence of a placebo control, are as yet poorly characterised or unknown. Minimum clinically important differences for these instruments have been established using well-controlled, blinded trials against a 
placebo comparator, thus hampering the clinical interpretation of data generated in open-label studies. As more open-label data on these outcomes become available in the future, this may help to clarify the clinical significance of treatment-associated changes observed in the open-label studies discussed above.

In conclusion, when reporting a clinical trial, it is important to be transparent about who exactly was blinded and how. If an open-label design is necessary, additional efforts should be made to minimise the risk of bias. If these recommendations are followed, and the data are considered in the full knowledge of any potential sources of bias, results with tiotropium suggest that data from open-label studies can provide valuable and credible evidence of the effects of a therapy.

\begin{abstract}
Abbreviations
B: Blinded; BDI: Baseline dyspnoea index; COPD: Chronic obstructive pulmonary disease; DB: Double-blind; DPI: Dry powder inhaler; FEV ${ }_{1}$ : Forced expiratory volume in 1 second; FVC: Forced vital capacity; ISBC: Independent study blinding co-ordinators; MCID: Minimal clinically important difference; OL: Open-label; RCTs: Randomised, controlled trials; SDDPI: Single dose dry powder inhaler; SGRQ: St. George's Respiratory Questionnaire; SVC: Slow vital capacity; TDI: Transition dyspnoea index; TPB: Third-party blinding.
\end{abstract}

\section{Competing interests}

$\mathrm{K}-\mathrm{MB}$ and $\mathrm{JB}$ have received compensation for organising or participating in advisory boards for Cytos, Boehringer Ingelheim, AstraZeneca, Novartis and Revotar Biopharmaceuticals. K-MB has participated as a speaker in scientific meetings or courses organised and financed by various pharmaceutical companies (AstraZeneca, Boehringer, Novartis, Pfizer and Takeda) in the past 5 years. The institution where K-MB and JB are currently employed has received compensations for the design, performance or participation in single or multicentre clinical trials in the past 5 years from several companies including Almirall Prodesfarma, Altana, AstraZeneca, Boehringer Ingelheim Cytos, GSK, Medapharma, Merck Sharp \& Dohme, Mundipharma, Novartis, Pfizer and Revotar Biopharmaceuticals.

JFD has served as a consultant and advisor and performed studies under contract for Novartis and Boehringer Ingelheim.

\section{Authors' contributions}

$\mathrm{K}-\mathrm{MB}, \mathrm{JB}$ and JFD conceived the review and participated in all stages of developing the manuscript. All authors have read and approved the final manuscript.

\section{Acknowledgements}

Editorial and project management assistance was provided by Melanie Stephens (CircleScience ${ }^{\circledR}$, London, UK). This assistance was funded by Novartis Pharma AG (Basel, Switzerland).

\section{Author details}

${ }^{1}$ Insaf Respiratory Research Institute, Wiesbaden, Germany. ${ }^{2}$ University of North Carolina, Chapel Hill, North Carolina, USA.

Received: 1 March 2012 Accepted: 8 June 2012

Published: 22 June 2012

\section{References}

1. Moher D, Hopewell S, Schulz KF, Montori V, Gøtzsche PC, Devereaux PJ, Elbourne D, Egger M, Altman DG: CONSORT 2010 explanation and elaboration: updated guidelines for reporting parallel group randomised trials. BMJ 2010, 340:c869.

2. ICH Harmonised tripartite Guideline (ICH E9): Statistical principles for clinical trials. 1998.

3. $\mathrm{CH}$ Harmonised tripartite Guideline (ICH E10): Choice of control group and related issues in clinical trials. 2000
4. Brand P, Hederer B, Austen G, Dewberry H, Meyer T: Higher lung deposition with Respimat Soft Mist inhaler than HFA-MDI in COPD patients with poor technique. Int J Chron Obstruct Pulmon Dis 2008, 3:763-770.

5. Chow S-C, Liu J-P: In Design and Analysis of Clinical Trials: Concepts and Methodologies, 2nd ed. Edited by Hoboken NJ. John Wiley \& Sons, Inc; 2004

6. Büller HR, Halpern JL, Bounameaux H, Prins M: Double-blind studies are not always optimum for evaluation of a novel therapy: the case of new anticoagulants. J Thromb Haemost 2008, 6:227-229.

7. Hansson L, Hedner T, Dahlöf B: Prospective randomized open blinded end-point (PROBE) study. A novel design of intervention trials. Blood Press 1992, 1:113-119.

8. Global Initiative for Chronic Obstructive Lung Disease (GOLD): Global strategy for the diagnosis, management, and prevention of chronic obstructive pulmonary disease (Updated 2010). http://www.goldcopd.com.

9. Donohue JF, Fogarty C, Lötvall J, Mahler DA, Worth H, Yorgancioglu A, lqbal A, Swales J, Owen R, Higgins M, Kramer B, INHANCE Study Investigators: Once-daily bronchodilators for chronic obstructive pulmonary disease: indacaterol versus tiotropium. Am J Respir Crit Care Med 2010, 182:155-162.

10. Vogelmeier C, Ramos-Barbon D, Jack D, Piggott S, Owen R, Higgins M, Kramer B, INTIME study investigators (INdacaterol \& Tlotropium: Measuring Efficacy): Indacaterol provides 24-hour bronchodilation in COPD: a placebo-controlled blinded comparison with tiotropium. Respir Res 2010, 11:135.

11. Buhl R, Dunn $\sqcup$, Disdier $C$, Lassen $C$, Amos C, Henley M, Kramer B, on behalf of the INTENSITY study investigators: Blinded 12-week comparison of oncedaily indacaterol and tiotropium in COPD. Eur Respir J 2011, 38:797-803.

12. Global initiative for chronic obstructive lung disease (GOLD): Global strategy for the diagnosis, management, and prevention of chronic obstructive pulmonary disease (Updated 2005).

13. Global initiative for chronic obstructive lung disease (GOLD): Global strategy for the diagnosis, management, and prevention of chronic obstructive pulmonary disease (Updated 2006). http://www.goldcopd.com.

14. Global initiative for chronic obstructive lung disease (GOLD): Global strategy for the diagnosis, management, and prevention of chronic obstructive pulmonary disease (Updated 2007).

15. Beeh KM, Beier J, Buhl R, Stark-Lorenzen P, Gerken F, Metzdorf N: Efficacy of tiotropium bromide (Spiriva) in patients with chronic-obstructive pulmonary disease (COPD) of different severities. Pneumologie 2006, 60:341-346.

16. Freeman D, Lee A, Price D: Efficacy and safety of tiotropium in COPD patients in primary care-the SPiRiva Usual CarE (SPRUCE) study. Respir Res 2007, 8:45

17. Johansson $G$, Lindberg $A$, Romberg $K$, Nordstrom $L$, Gerken F, Roquet A: Bronchodilator efficacy of tiotropium in patients with mild to moderate COPD. Prim Care Respir J 2008, 17:169-175.

18. Moita J, Barbara C, Cardoso J, Costa R, Sousa M, Ruiz J, Santos ML: Tiotropium improves FEV1 in patients with COPD irrespective of smoking status. Pulm Pharmacol Ther 2008, 21:146-151.

19. Verkindre C, Bart F, Aguilaniu B, Fortin F, Guérin JC, Le Merre C, lacono P, Huchon G: The effect of tiotropium on hyperinflation and exercise capacity in chronic obstructive pulmonary disease. Respiration 2006, 73:420-427.

20. Niewoehner DE, Rice K, Cote C, Paulson D, Cooper JA Jr, Korducki L, Cassino C, Kesten S: Prevention of exacerbations of chronic obstructive pulmonary disease with tiotropium, a once-daily inhaled anticholinergic bronchodilator: a randomized trial. Ann Intern Med 2005, 143:317-326.

21. Brusasco V, Hodder R, Miravitlles M, Korducki L, Towse L, Kesten S: Health outcomes following treatment for six months with once daily tiotropium compared with twice daily salmeterol in patients with COPD. Thorax 2003, 58:399-404.

22. Tonnel AB, Perez T, Grosbois JM, Verkindre C, Bravo ML, Brun M: Effect of tiotropium on health-related quality of life as a primary efficacy endpoint in COPD. Int J Chron Obstruct Pulmon Dis 2008, 3:301-310.

23. Chan CK, Maltais F, Sigouin C, Haddon JM, Ford GT: A randomized controlled trial to assess the efficacy of tiotropium in Canadian patients with chronic obstructive pulmonary disease. Can Respir J 2007, 14:465-472.

24. Casaburi R, Mahler DA, Jones PW, Wanner A, San PG, ZuWallack RL, Menjoge SS, Serby CW, Witek T Jr: A long-term evaluation of once-daily 
inhaled tiotropium in chronic obstructive pulmonary disease. Eur Respir J 2002, 19:217-224.

25. Tashkin DP, Celli B, Senn S, Burkhart D, Kesten S, Menjoge S, Decramer M: UPLIFT Study Investigators: A 4-year trial of tiotropium in chronic obstructive pulmonary disease. N Engl J Med 2008, 359:1543-1554.

26. Committee for proprietary medicinal products (CPMP): Points to consider in on clinical investigations of medicinal products in the chronic treatment of patients with chronic obstructive pulmonary disease (COPD). 1999 www.ema. europa.eu/pdfs/human/ewp/056298en.pdf.

27. Jones PW, Quirk FH, Baveystock CM, Littlejohns P: A self-complete measure of health status for chronic airflow limitation. The St. George's Respiratory Questionnaire. Am Rev Respir Dis 1992, 145:1321-1327.

28. Jones PW: St. George's Respiratory Questionnaire: MCID. J COPD 2005, 2:75-79.

29. Yorgancioğlu A, Mahler DA, labal A, Owen R, Higgins M, Kramer B: Indacaterol once-daily improves health-related quality of life in COPD patients: a 26-week comparison with placebo and tiotropium. Poster presented at the European Respiratory Society Conference. Vienna, Austria: Abstract: 2028; 2009.

30. Jones P, Lareau S, Mahler DA: Measuring the effects of COPD on the patient. Respir Med 2005, 99(Suppl B):S11-S18.

31. Mahler DA, Weinberg DH, Wells CK, Feinstein AR: The measurement of dyspnea. Contents, interobserver agreement, and physiologic correlates of two new clinical indexes. Chest 1984, 85:751-758.

32. Witek TJ Jr, Mahler DA: Minimal important difference of the transition dyspnoea index in a multinational clinical trial. Eur Respir J 2003, 21:267-272.

33. Mahler DA, Witek TJ Jr: The MCID of the transition dyspnea index is a total score of one unit. J COPD 2005, 2:99-103.

34. Schulz KF, Chalmers I, Hayes RJ, Altman DG: Empirical evidence of bias. Dimensions of methodological quality associated with estimates of treatment effects in controlled trials. JAMA 1995, 273:408-412.

35. Moher D, Pham B, Jones A, Cook DJ, Jadad AR, Moher M, Tugwell P, Klassen TP: Does quality of reports of randomised trials affect estimates of intervention efficacy reported in meta-analyses? Lancet 1998, 352:609-613.

36. Kjaergard LL, Villumsen J, Gluud C: Reported methodologic quality and discrepancies between large and small randomized trials in metaanalyses. Ann Intern Med 2001, 135:982-989.

37. Egger $M$, Juni $P$, Bartlett $C$, Holenstein F, Sterne J: How important are comprehensive literature searches and the assessment of trial quality in systematic reviews? Empirical study. Health Technol Assess 2003, 7:1-76.

38. Balk EM, Bonis PA, Moskowitz H, Schmid CH, loannidis JP, Wang C, Lau J: Correlation of quality measures with estimates of treatment effect in metaanalyses of randomized controlled trials. JAMA 2002, 287:2973-2982.

39. Als-Nielsen B, Chen W, Lotte Gluud L, Siersma V, Hilden J, Gluud C: Are trial size and reported methodological quality associated with treatment effects? Observational study of 523 randomised trials. Ottawa, Canada: 12th Cochrane Colloquium; 2004 http://www.imbi.uni-freiburg.de/OJS/cca/index.php/cca/ article/view/2616.

40. Als-Nielsen B, Lotte Gluud L, Gluud C: Methodological quality and treatment effects in randomised trials: a review of six empirical studies. Ottawa, Canada: 12th Cochrane Colloquium; 2004. http://www.imbi.uni-freiburg.de/OJS/cca/ index.php/cca/article/view/2594.

41. Moses LE: Measuring effects without randomized trials? Options, problems, challenges. Med Care 1995, 33(Suppl):AS8-AS14.

42. Kunz R, Oxman AD: The unpredictability paradox: review of empirical comparisons of randomised and non-randomised clinical trials. BMJ 1998, 317:1185-1190.

43. Benson K, Hartz AJ: A comparison of observational studies and randomized, controlled trials. N Engl J Med 2000, 342:1878-1886.

44. Wood L, Egger M, Gluud LL, Schulz KF, Jüni P, Altman DG, Gluud C, Martin RM, Wood AJ, Sterne JA: Empirical evidence of bias in treatment effect estimates in controlled trials with different interventions and outcomes: meta-epidemiological study. BMJ 2008, 336:601-605.

45. American Thoracic Society/European Respiratory Society (ATS/ERS) Series: ATS/ERS Task Force: Standardisation of lung function testing. Eur Respir J 2005, 26:153-968. Brusasco V, Crapo R, Viegi G.

doi:10.1186/1465-9921-13-52

Cite this article as: Beeh et al:: Clinical trial design in chronic obstructive pulmonary disease: current perspectives and considerations with regard to blinding of tiotropium. Respiratory Research 2012 13:52.

\section{Submit your next manuscript to BioMed Central and take full advantage of:}

- Convenient online submission

- Thorough peer review

- No space constraints or color figure charges

- Immediate publication on acceptance

- Inclusion in PubMed, CAS, Scopus and Google Scholar

- Research which is freely available for redistribution 